\title{
METODE GROUP TO GROUP EXCHANGE (GGE) TERHADAP HASIL BELAJAR IPS DI SEKOLAH DASAR
}

\author{
${ }^{1}$ Achmad Reza Eka Putra, ${ }^{2}$ Sa'odah Sa'odah, ${ }^{3}$ Asih Rosnaningsih \\ ${ }^{1,2,3}$ Universitas Muhammadiyah Tangerang, Indonesia \\ Email : $\underline{\text { saodah@umt.ac.id }}$
}

\begin{abstract}
Abstrak
Penelitian ini adalah untuk menentukan perbedaan hasil belajar siswa dalam mata pelajaran ilmu sosial tentang komunikasi, transportasi dan teknologi produksi antara siswa yang diberi metode pembelajaran Group To Group Exchange (GGE) dan siswa yang diberikan pengajaran konvensional. Penelitian ini menggunakan metodologi quasi eksperimental. Populasi subjek dalam penelitian ini adalah semua siswa kelas IV SDN Perigi 04 yang terdiri dari 50 siswa kelas VA yang terdiri dari 25 siswa sebagai kelas eksperimen dan kelas VB yang terdiri dari 25 siswa sebagai kelas kontrol. Teknik pengumpulan data menggunakan instrumen hasil pembelajaran pada tes kemampuan ilmu sosial berupa esai yang terdiri dari 15 soal yang valid dan realible. Untuk menguji hipotesis uji $\mathrm{t}$ pretest yang digunakan dalam penelitian ini, dari hasil uji $\mathrm{t}$ diperoleh $\mathrm{t}$ hitung $=2,5$ dan $\mathrm{t}$ tabel $=2,02$, sehingga dapat disimpulkan bahwa ada perbedaan antara nilai rata-rata kelas kontrol dan kelas eksperimen pretest. Sedangkan untuk menguji hipotesis posttest dari uji t diperoleh $\mathrm{t}$ hitung $=31,9$ dan $\mathrm{t}$ tabel $=2,02$, sehingga dapat disimpulkan bahwa ada perbedaan yang signifikan antara skor rata-rata kelas kontrol posttest dan kelas eksperimen. Ini berarti bahwa hasil belajar IPS menggunakan metode pembelajaran Group To Group Exchange (GGE) lebih tinggi daripada menggunakan model pembelajaran konvensional
\end{abstract}

Kata kunci: Group To Group Exchange (GGE), Hasil Belajar, IPS

\begin{abstract}
This study was to determine the differences in student learning outcomes in social science subjects about communication, transportation and production technology between students who were given the Group To Group Exchange (GGE) learning method and students who were given conventional teaching. This study uses a quasi experimental methodology. The subject population in this study were all fourth grade students of SDN Perigi 04 which consisted of 50 VA class students consisting of 25 students as the experimental class and the VB class consisting of 25 students as the control class. The data collection technique used the learning outcome instrument on the social science ability test in the form of an essay consisting of 15 valid and realistic questions. To test the pretest $t$ test hypothesis used in this study, from the t test results obtained $t$ count $=2.5$ and t table $=$ 2.02, so it can be concluded that there is a difference between the mean score of the control class and the pretest experimental class. Meanwhile, to test the posttest hypothesis from the t test obtained $t$ count $=31.9$ and t table $=2.02$, so it can be concluded that there is a significant difference between the mean score of the posttest control class and the experimental class. This means that the social studies learning outcomes using the Group To Group Exchange (GGE) learning method are higher than using conventional learning models
\end{abstract}

Keywords: Group To Group Exchange (GGE), Learning Outcomes, Social Studies 


\section{PENDAHULUAN}

Pendidikan sekolah dasar pada dasarnya merupakan lembaga pendidikan yang menyelenggarakan program pendidikan enam tahun bagi anak-anak usia 6-12 tahun. Pendidikan sekolah dasar dimaksud untuk memberikan bekal kemampuan dasar kepada anak didik berupa pengetahuan, keterampilan, dan sikap yang bermanfaat bagi dirinya sesuai dengan tingkat perkembangan.

Mewujudkan suasana belajar dan proses belajar yang baik tentunya sangat ditentukan oleh guru dan siswa. Proses pembelajaran yang dikatakan berhasil ditentukan oleh bagaimana proses pembelajaran tersebut berlangsung. Seorang guru harus dapat membawakan suasana belajar yang nyaman dan menyenangkan. Penggunaan metode yang bervariasi akan menjadikan proses pembelajaran lebih bermakna, sehingga siswa dapat meningkatkan prestasi belajarnya. Jenjang pendidikan dasar merupakan peranan yang sangat penting dalam mengembangkan aspek fisik, intelektual, religius, moral, sosial, emosi, pengetahuan, dan pengalaman peserta didik. Melalui pendidikan dasar, diharapkan dapat menghasilkan manusia Indonesia yang berkualitas.

Belajar IPS dapat mengembangkan bakat, minat, kemampuan dan lingkungannya, sehingga IPS dapat mengembangkan segala potensi yang ada pada diri siswa. IPS juga membantu dalam menyiapkan siswa untuk masuk ke dalam kehidupan sosial. Demi terwujudnya tujuan tersebut, pembelajaran IPS harus dilaksanakan dengan baik. Salah satu komponen dalam pembelajaran khususnya pembelajaran IPS adalah metode pembelajaran. Metode pembelajaran IPS harus sesuai dengan pembelajaran yang akan dilaksanakan. Metode pembelajaran juga harus mengajak siswa berperan aktif dalam pembelajajaran, agar pembelajaran lebih bermakna dan tujuan pembelajaran IPS dapat tercapai dengan baik.

Observasi yang dilakukan oleh peneliti pada pembelajaran IPS di kelas IV SDN Perigi 04 Tangerang Selatan pada tanggal 25 Januari 2018 terlihat ada beberapa permasalahan yang teramati. Pertama, Rendahnya hasil belajar siswa yang ditunjukkan dengan banyaknya nilai siswa berada di bawah Kriteria Ketuntasan Minimal dengan nilai 60 yaitu sejumlah 24 (48\%) siswa, diatas Kriteria Ketuntasan Minimal 23 (46\%) siswa, dan pas Kriteria Ketuntasan Minimal (6\%) 3 siswa dari 50 siswa yang ada. Kedua, pengelolaan kelas yang masih kurang optimal. Ada beberapa siswa yang asyik berbicara dengan teman sebangkunya saat pelajaran berlangsung. Ketiga, keaktifan siswa yang masih kurang. Hal ini terlihat ketika pembelajaran 
berlangsung, siswa lebih banyak mendengarkan ceramah dari guru. Keempat, antusias siswa terhadap media masih kurang. Guru sudah menggunakan media pembelajaran, yaitu media gambar. Guru sudah menampilkan gambar-gambar maupun informasi yang terkait dengan pembelajaran IPS. Namun demikian, siswa kurang antusias terhadap media tersebut. Kelima, penggunaan metode ceramah dan tanya jawab merupakan metode pembelajaran yang digunakan oleh guru. Guru lebih mendominasi aktivitasnya dibandingkan siswa.

Hasil belajar seringkali digunakan sebagai ukuran untuk mengetahui seberapa jauh seseorng menguasai bahan yang sudah diajarkan. Untuk mengaktualisasikan hasil belajar tersebut diperlukan serangkaian pengukuran menggunakan alat evaluasi yang baik dan memenuhi syarat. Pengukuran demikian dimungkinkan karena pengukuran merupakan kegiatan ilmiah yang dapat diterapkan pada berbagai bidang termasuk pendidikan.

Menurut Winkel (1996) hasil belajar adalah perubahan yang mengakibatkan manusia berubah dalam sikap dan tingkah lakunya. Aspek perubahan itu mengacu kepada taksonomi tujuan pengajaran yang dikembangkan oleh Bloom, Simpson dan Harrow mencakup aspek kognitif, afektif dan psikomotorik. (Purwanto, 2016, h. 45). Senada dengan pendapat Hamalik (2006) yang memukakan bahwa hasil belajar adalah bila seseorag telah belajar akan terjadi perubahan tingkah laku pada orang tersebut, misalnya tidak tahu menjadi tahu, dan dari tidak mengerti menjadi mengerti (Kustawan, 2016, h. 15). Sementara itu menurut Sudjana (2004) hasil belajar adalah kemampuan-kemampuan yang dimiliki siswa setelah menerima pengalaman belajarnya (Kustawan, 2016, h. 15). Dari beberapa pendapat tentang pengertian hasil belajar dapat disimpulkan bahwa hasil belajar adalah perubahan perilaku yang terjadi setelah mengikuti proses belajar mengajar sesuai dengan tujuan pendidikan yang dapat mengubah seseorang dari tidak mengerti menjadi mengerti dengan meliputi aspek kognitif, afektif dan psikomotorik.

Menurut Trianto (2010) Ilmu pengetahuan sosial (IPS) merupakan mata pelajaran wajib di Sekolah Dasar (SD). IPS di SD adalah pengintegrasian atau penggabungan dari berbagai cabang ilmu sosial. IPS merupakan integrasi dari berbagai cabang ilmu-ilmu sosial, seperti sosiologi, sejarah, geografi, ekonomi, politik, hukum, dan budaya (h. 171). Sedangkan menurut Sardjiyo (2011), "IPS adalah bidang studi yang mempelajari, menelaah, menganalisis gejala dan masalah sosial di masyarakat dengan meninjau dari berbagai aspek kehidupan atau suatu perpaduan" (h.126). Sementara itu menurut Arnie Fajar (2009) juga 
menjelaskan bahwa, "IPS adalah mata pelajaran yang mengkaji seperangkat peristiwa, fakta, konsep, dan generalisasi yang berkaitan dengan isu sosial dan kewarganegaraan” (h. 110). Dari beberapa pendapat para ahli tersebut, dapat dikatakan bahwa IPS di SD adalah mata pelajaran yang mengintegrasikan berbagai cabang-cabang ilmu sosial seperti sosiologi, sejarah, geografi, ekonomi, politik, hukum, dan budaya dan segala aspek permasalahan atau isu sosial yang ada dalam kehidupan sehari-hari. Dengan demikian, hasil belajar IPS merupakan hasil optimal siswa baik dalam aspek kognitif, afektif, ataupun psikomotorik yang diperoleh siswa setelah memperlajari IPS dengan jalan mencari berbagai informasi yang dibutuhkan baik berupa perubahan tingkah laku, pengetahuan, maupun keterampilan sehingga siswa tersebut mampu mencapai hasil maksimal belajarnya sekaligus memecahkan masalah yang berkaitan dengan masalah sosial dan menerapkannya dalam kehidupan masyarakat.

Pembelajaran aktif merupakan induk pembelajaran dari model- model pembelajaran lain. Pembelajaran aktif atau active learning menuntun siswa untuk selalu aktif dalam pembelajaran. Pembelajaran aktif juga mengharuskan pembelajaran yang berpusat pada siswa atau student centered, sehingga aktivitas siswa lebih mendominasi dari pada aktivitas guru. Dengan demikian pembelajaran dengan menekankan keaktifan siswa akan lebih bermakna dan menjadikan pembelajaran lebih berkesan bagi siswa. Menurut Warsono dan Hariyanto (2013) "Pembelajaran aktif secara sederhana didefiniskan sebagai metode pengajaran yang melibatkan siswa secara aktif dalam proses pembelajaran. Pembelajaran akif mengkondisikan agar siswa selalu melakukan pengalaman belajar yang bermakna dan senantiasa berpikir tentang apa yang dapat dilakukannya selama pembelajaran" Tujuan dari pembelajaran aktif adalah memaksimalkan segala potensi yang ada dalam diri siswa, mengajak siswa untuk selalu aktif dalam pembelajaran, menjadikan pembelajaran lebih bermakna dan berkesan. Pembelajaran aktif mengajak siswa untuk selalu ikut serta dalam pembelajaran. Sementara itu tugas guru dalam pembelajaran aktif yaitu sebagai fasilitator. Peran fungsional guru dalam pebelajaran aktif yang utama adalah sebagai fasilitator. Fasilitator merupakan seseorang yang membantu memberikan fasilitas pada peserta didik untuk belajar dan memiliki keterampilan keterampilan yang diperlukan dalam mencapai tujuan pembelajaran yang ingin dicapai. Sebagai fasilitator, seorang guru harus menguasai segala aspek pembelajaran sehingga pembelajaran aktif dapat berjalan dengan lancar. 
Metode Group to Group Exchange (GGE) atau yang dikenal dengan pertukaran kelompok dengan kelompok merupakan salah satu metode pembelajaran aktif. Pembelajaran Group To Group Exchange atau disebut model pembelajaran pertukaran kelompok mengajar ini, tugas yang berbeda diberikan kepada kelompok peserta didik yang berbeda. Masing-masing kelompok "mengajar" apa yang telah dipelajari untuk siswa kelas (Depdiknas, 2004, h. 25). Senada dengan Silberman (2006) menyatakan metode GGE adalah memberikan tugas berbeda kepada para kelompok peserta yang kemudian setiap kelompok "mengerjakan" apa yang dipelajari kepada semua kelompok peserta. Metode GGE ini menuntut siswa untuk selalu aktif dalam pembelajaran, dan diminta untuk saling mengajarkan kepada sesama siswa (Hidayat, 2009, h. 166). Sementara itu menurut Prayogo dan Ayu Silviana (2010) metode $G G E$ adalah Suatu format diskusi yang memberikan tugas-tugas yang berbeda diberikan kepada kelompok siswa yang berbeda. Metode $G G E$ menuntut siswa untuk berfikir tentang apa yang siswa pelajari, memberi kesempatan berdiskusi atau bersosialisasi dengan teman, bertanya dan berbagi pengetahuan kepada teman lainnya. Metode $G G E$ merupakan pembelajaran yang menerapkan langkah cepat, menyenangkan, mendukung dan menarik hati (Wijayanto, 2014, h.30). Berdasarkan pengertian dari ketiga ahli tersebut, metode $G G E$ memiliki ciri khas membagikan tugas yang berbeda-beda tiap kelompoknya, kemudian kelompok ini dibagi secara heterogen agar terjadi keragaman pada setiap kelompok. Permasalahan atau tugas yang berbeda-beda pada setiap kelompok akan memberikan kesempatan untuk berinteraksi antar kelompok untuk saling bertukar materi atau permasalahan yang diterimanya dan dituntut untuk menjelaskan kepada temannya tentang tugas yang diterimanya.

Menurut Prayogo dan Ayu Silviana (2010) tujuan penggunaan metode GGE adalah memungkinkan siswa belajar lebih aktif serta melatih tanggung jawab dan kepemimpinan pada diri siswa, siswa juga akan termotivasi dalam mengikuti kegiatan belajar dan semua siswa akan memperoleh banyak pengetahuan dan pengalaman. Kemudian dijelaskan juga bahwa melalui metode $G G E$ siswa mampu berinteraksi secara terbuka, berdialog, dan intreaktif dibawah bimbingan guru dan tutor sebaya, sehingga siswa termotivasi untuk menguasai bahan ajar yang disajikan (Wijayanto, 2014, h.31). Hal senada juga diungkapkan berdasarkan hasil penelitian Murni et al,. bahwa penerapan metode GGE dapat meningkatkan hasil belajar (Murni et al., 2010; Sahid, 2013). Dengan demikian metode GGE 
merupakan pengintegrasian antara metode diskusi, tanya jawab dan pengajaran terhadap sesama teman serta melatih siswa agar mampu bersosialisasi dengan teman lain dan saling bertukar pengalaman yang berbeda- beda untuk mencapai tujuan bersama. Metode GGE ini melibatkan siswa aktif secara berkelompok yang heterogen, sementara guru sebagai fasilitator yang membimbing apabila ada kesalahan.

Materi untuk hasil belajar IPS yaitu tentang teknologi, komunikasi, produksi dan transportasi. Menurut Roger (1983) teknologi adalah suatu rancangan (desain) untuk alat bantu tindakan yang mengurangi ketidakpastian dalam hubungan sebab akibat dalam mencapai suatu hal yang diinginkan (Ananda, 2015, h.3). Sedangkan menurut Heinich, Molenda, dan Russell (1993) Teknologi merupakan penerapan pengetahuan yang ilmiah, dan tertata. Teknologi sebagai suatu proses atau cara berpikir bukan hanya produk seperti komputer, satelit, dan sebagainya (Erwinsyah, 2015, h. 13). Dari beberapa pendapat para ahli tersebut, dapat dikatakan Teknologi adalah keseluruhan sarana untuk menyediakan barangbarang yang diperlukan bagi kelangsungan dan kenyamanan hidup manusia. Secara umum, teknologi dapat didefinisikan sebagai entitas, benda maupun tak benda yang diciptakan secara terpadu melalui perbuatan dan pemikiran untuk mencapai suatu nilai. Menurut Basrowi (2013) Komunikasi adalah suatu proses saling memberikan tafsiran kepada atau dari perilaku pihak lain. Melalui tafsiran pada perilaku pihak lain, seorang dapat mewujudkan perilaku sebagai reaksi terhadap maksud atau peran yang ingin disampaikan oleh pihak lain itu (h. 143). Senada dengan Sarlito (2012) yang berpendapat bahwa "Komunikasi adalah pengiriman berita dari seseorang kepada orang lainnya" (h, 185). Berbeda dengan Bungin (2013) yang menjelaskan bahwa Komunikasi adalah sebagai sebuah proses memaknai yang dilakukan oleh seseorang (I) terhadap informasi, sikap, dan perilaku orang (II) lain yang berbentuk pengetahuan, pembicaraan, gerak-gerik, atau sikap perilaku dan perasaan-perasaan, sehingga seseorang (I) membuat reaksi terhadap informasi, sikap, dan perilaku tersebut berdasarkan pada pengalaman yang pernah dia (I) alami (h. 57). Dari beberapa pendapat para ahli tersebut, dapat dikatakan Komunikasi adalah proses pengiriman dan penerimaan informasi atau pesan antara dua individu atau lebih dengan efektif sehingga bisa dipahami dengan mudah. Dengan demikian Teknologi Komunikasi adalah keseluruhan sarana untuk menyediakan barang-barang yang diperlukan bagi kelangsungan dan kenyamanan hidup 
manusia untuk proses pengiriman dan penerimaan informasi atau pesan antara dua individu atau lebih dengan efektif sehingga bisa dipahami dengan mudah.

Miller dan Meiners, 2000 Istilah "produksi” secara umum diartikan sebagai penggunaan atau pemanfaatan sumber daya yang mengubah suatu komoditi menjadi komoditi lainnya yang sama sekali berbeda, baik dalam pengertian apa, dan dimana atau kapan komoditi- komoditi itu dialokasikan, maupun dalam pengertian apa yang dapat dikerjakan oleh konsumen oleh komoditi itu (Kurniasi dan Poerwono, 2008, h. 7). Sedangkan (Gumbira dan Harizt, 2001) Produksi dapat didefinisikan sebagai suatu proses yang menciptakan atau menambah nilai / guna atau manfaat baru. Guna atau manfaat mengandung pengertian kemampuan barang atau jasa untuk memenuhi kebutuhan manusia. Jadi produksi meliputi semua aktivitas menciptakan barang dan jasa (Ginting, 2013, h. 4). Dari beberapa pendapat para ahli tersebut, dapat dikatakan Produksi merupakan suatu proses yang menciptakan atau menambah nilai / guna atau manfaat baru dengan memanfaatkan sumber daya yang mengubah sesuatu menjadi sesuatu yang berbeda. Dengan demikian Teknologi Produksi adalah sarana untuk menyediakan barang-barang yang diperlukan bagi kelangsungan dan kenyamanan hidup manusia untuk menciptakan atau menambah nilai / guna atau manfaat baru dengan memanfaatkan sumber daya yang mengubah sesuatu menjadi sesuatu yang berbeda. Dengan demikian Teknologi Produksi adalah sarana untuk menyediakan barangbarang yang diperlukan bagi kelangsungan dan kenyamanan hidup manusia untuk menciptakan atau menambah nilai / guna atau manfaat baru dengan memanfaatkan sumber daya yang mengubah sesuatu menjadi sesuatu yang berbeda.

Menurut Nasution (1996) Transportasi diartikan sebagai pemindahan barang dan manusia dari tempat asal ke tempat tujuan. Sehingga dengan kegiatan tersebut maka terdapat tiga hal yaitu adanya muatan yang diangkut, tersedianya kendaraan sebagai alat angkut, dan terdapatnya jalan yang dapat dilalui (Siloandae dkk, 2016, h. 51). Sedangkan Menurut Miro (2005) transportasi dapat diartikan usaha memindahkan, mengerakkan, mengangkut, atau mengalihkan suatu objek dari suatu tempat ke tempat lain, di mana di tempat lain ini objek tersebut lebih bermanfaat atau dapat berguna untuk tujuan-tujuan tertentu (Adriansyah, 2016, h. 1). Dengan demikian teknologi Transportasi adalah sarana untuk menyediakan barangbarang yang diperlukan bagi kelangsungan dan kenyamanan hidup manusia untuk memindahkan barang dan manusia dari tempat asal ke tempat lain. 
Untuk mengetahui ada tidaknya pengaruh metode pembelajaran Group To Group Exchange terhadap hasil belajar IPS, maka penulis hendak meneliti masalah tersebut dan mengambil judul "Pengaruh Metode Group To Group Exchange (GGE) Terhadap Hasil Belajar IPS Kelas IV SD Negeri Perigi 04 Tangerang Selatan”.

\section{METODE PENELITIAN}

Metode yang digunakan dalam penelitian kuantitatif ini adalah metode Quasi Eksperimental jenis Non Equivalent Control Group Design. Penelitian dilakukan pada bulan Januari - September 2018. Populasi dalam penelitian ini adalah siswa kelas IV SD Negeri Perigi 04 Tangerang Selatan yang berjumlah 50 siswa yang terdiri dari kelas IV A 25 siswa dan kelas IV B 25 siswa. Yang dijadikan sampel dalam peneltian ini adalah kelas IV A sebagai kelas eksperimen dan kelas IV B sebagai kelas kontrol. Adapun teknik pengambilan sampel menggunakan Sample Jenuh.

Data dalam penelitian ini berupa data kuantitatif. Data kuantitatif berupa hasil belajar tentang materi teknologi komunikasi, transportasi dan produksi. Terdiri dari 15 soal untuk melihat pengaruh dari pemberian perlakuan terhadap kelas eksperimen maupun kelas kontrol, maka baik kelas eksperimen maupun kelas kontrol diberikan pretes dan postes. Sebelum tes diberikan, dilakukan uji validitas dan reliabilitas terlebih dahulu. Untuk pretes dan postes digunakan perangkat tes yang berbeda. Data hasil penelitian yang diperoleh selanjutnya dianalisis statistik deskriptif dan inferensial. Pengujian terhadap perbedaan rata-rata hasil postest menggunakan teknik statistik independent sample t test.

\section{HASIL DAN PEMBAHASAN}

Hasil penelitian dapat dilihat dari Tabel 1 berikut ini:

\section{Tabel 1}

Hasil Analisis Deskriptif Pretest dan Postest Kemampuan Berpikir Kritis

Kelas Eksperimen dan Kelas Kontrol

\begin{tabular}{|l|l|l|l|l|l|l|l|l|}
\hline & Kelas & N & Min & Max & Mean & Modus & Median & SD \\
\hline Pretes & Eksperimen & 25 & 31 & 84 & 49,4 & 44 & 46,8 & 14,118 \\
\hline
\end{tabular}


Indonesian Journal of Elementary Education

Vol. 2, No. 1, Desember 2020

E-ISSN: 2722-6689

http://jurnal.umt.ac.id/index.php/IJOEE

\begin{tabular}{|l|l|l|l|l|l|l|l|l|}
\hline Postes & & & 73 & 96 & 82,82 & 78,5 & 80,04 & 5,715 \\
\hline Pretes & \multirow{2}{*}{ Kontrol } & \multirow{2}{*}{25} & 20 & 62 & 40,1 & 31,75 & 37,7 & 11,5 \\
\cline { 4 - 9 } & & & 20 & 45 & 29,2 & 25,86 & 30,25 & 6,124 \\
\hline
\end{tabular}

Berdasarkan Tabel 1, nilai pretest pada kelompok eksperimen menunjukkan nilai minimum 31 dan maksimum 84 dan untuk nilai postest menunjukkan nilai minimum 73 dan maksimum 96. Kelompok kontrol nilai pretest menunjukkan nilai minimum 20 dan maksimum 62 dan untuk nilai postest menunjukkan nilai minimum 20 dan maksimum 45 . Sehingga disimpulkan nilai pretest maupun postest kelompok eksperimen lebih tinggi dari kelompok kontrol. Hal ini juga dapat dilihat pada Tabel 3 :

Tabel 2

Ringkasan Nilai Pretes dan Postes

\begin{tabular}{|l|l|l|}
\hline Kelas & Rata-rata nilai pretes & Rata-rata nilai postes \\
\hline Eksperimen & 49,4 & 82,82 \\
\hline Kontrol & 40,1 & 29,2 \\
\hline
\end{tabular}

Pada Tabel 2, menunjukkan bahwa kelas eksperimen lebih tinggi dari kelas kontrol, kedua kelas tergolong dalam kategori sedang. Berdasarkan hasil analisis uji t pada variabel keterampilan proses sains Antara kelompok eksperimen dan kelompok kontrol ditunjukkan pada Tabel 3.

Tabel 3

Uji-t Tes Akhir Hasil Belajar

Kelas Eksperimen dan Kelas Kontrol

\begin{tabular}{|c|c|c|}
\hline \multirow[t]{2}{*}{ Uji-T } & $\mathbf{T}_{\text {hitung }}$ & $\begin{array}{l}T_{\text {tabel }}\left(1-\frac{\alpha}{2}\right)^{t}\left(n_{1}+n_{2}-\right. \\
2)\end{array}$ \\
\hline & 31,9 & 2,02 \\
\hline
\end{tabular}

Dari tabel 3 tersebut dapat dilihat hasil pengujian $t_{\text {hitung }}>t_{\text {tabel }}$ maka $\mathrm{H}_{0}$ ditolak, $\mathrm{H}_{1}$ diterima artinya terdapat perbedaaan hasil belajar Ilmu Pengetahuan Sosial (IPS) materi Teknologi Komunikasi, Transportasi dan Produksi antara siswa yang diberi metode 
pembelajaran Group To Group Exchange $(G G E)$ dengan yang diberi model pembelajaran konvensional.

Dengan diterimanya $\mathrm{H}_{1}$ dapat disimpulkan bahwa terdapat perbedaan hasil belajar IPS menggunakan metode Group To Group Exchange (GGE) dengan menggunakan model konvensional. Hasil pengujian ini sekaligus membuktikan bahwa terjadi perbedaan hasil belajar IPS siswa bukan suatu kebetulan, melainkan karena perbedaan pelakuan yang diberikan kepada kelas eksperimen dan kelas kontrol. Sehingga dapat disimpulkan bahwa dengan memberikan perlakuan menggunakan metode Group To Group Exchange (GGE) terhadap hasil belajar siswa dapat berpengaruh positif, serta efisiensi proses belajar mengajar IPS dapat ditingkatkan menggunakan metode pembelajaran tersebut.

Setelah dilakukan pembelajaran materi teknologi komunikasi, transportasi dan produksi dengan menggunakan metode Group To Group Exchange (GGE) pada kelas eksperimen dan model pembelajaran konvensional pada kelas kontrol, didapatkan perbedaan hasil belajar dari kelas eksperimen masuk dalam kategori baik, sedangkan untuk kelas kontrol masuk dalam kategori cukup. Hasil penelitian dapat disimpulkan bahwa hasil pengujian postes $t_{\text {hitung }}=$ $31,90>2,02=t_{\text {tabel }}$ maka $\mathrm{H}_{0}$ ditolak dan $\mathrm{H}_{1}$ diterima. Artinya terdapat perbedaaan hasil belajar Ilmu Pengetahuan Sosial (IPS) materi Teknologi Komunikasi, Transportasi dan Produksi antara siswa yang diberi metode pembelajaran Group To Group Exchange (GGE) dengan yang diberi model pembelajaran konvensional. Dengan demikian, perlakuan kegiatan pembelajaran pada kelas eksperimen dan kelas kontrol berpengaruh terhadap hasil belajar IPS siswa. Hal ini berarti kegiatan pembelajaran yang dialami siswa menentukan tingkat hasil belajar. Pada kelas eksperimen yang di desain dengan metode pembelajaran Group To Group Exchange (GGE) memberikan pengaruh lebih baik terhadap hasil belajar siswa dibandingkan menggunakan model pembelajaran konvensional.

\section{SIMPULAN DAN SARAN}

Hasil penelitian yang telah dilakukan menunjukkan bahwa dengan menggunakan metode pembelajaran Group To Group Exchange (GGE) berpengaruh dan dapat meningkatkan hasil belajar IPS siswa, dengan kata lain terdapat Pengaruh Metode Group To Group Exchange (GGE) Terhadap Hasil Belajar IPS Kelas IV SD Negeri Perigi 04 Tangerang Selatan. Penerapan pembelajaran di kelas dapat membuat siswa lebih aktif dan 
Indonesian Journal of Elementary Education

Vol. 2, No. 1, Desember 2020

E-ISSN: 2722-6689

http://jurnal.umt.ac.id/index.php/lJOEE

kreatif, serta saling membantu dan berdiskusi satu sama lain dalam memecahkan masalah yang ada, karena belajar aktif dan kreatif dapat meningkatkan suatu pemikiran yang lebih tinggi pada masing-masing siswa.

\section{DAFTAR PUSTAKA}

Ananda (2015). Studi Deskriptif Mengenai Pemanfaatan Teknologi Informasi pada SMK Negeri 1 dan SMK Negeri 4 Surabaya.

Andriansyah (2015). Manajemen Transportasi Dalam Kajian Teori. Jakarta: Universitas Prof. Dr. Moestopo Beragama.

Basrowi (2014). Pengantar Sosiologi. Bogor: Ghalia Indonesia

Bungin (2013). Sosiologi Komunikasi. Jakarta: Kencana Prenada Media Group

Depdiknas (2004). Materi Pelatihan Terintegrasi Mata Pelajaran Sains. Dirjen Pendidikan Dasar dan Menengah.

Erwinsyah (2015). Pemahaman Mengenai Teknologi Pendidikan dan Teknologi Pembelajaran. Jurnal Manajemen Pendidikan Islam, 13.

Fajar, A. (2009). Portofolio dalam Pembelajaran IPS. Bandung: Remaja Rosdakarya.

Ginting (2013). Faktor-Faktor yang Mempengaruhi Produksi Padi dan Kontribusinya Terhadap Pendapatan Keluarga Petani. Jurnal Ilmiah Pendidikan Tinggi, 4.

Hariyanto \& Warsono (2013). Pembelajaran Aktif. Bandung: Remaja Rosdakarya

Hidayat, K. (2009). Active Learning 101 Strategi Pembelajaran Aktif. Yogyakarya: Pustaka Insan Madani.

Kurniasi \& Poerwono (2008). Analisis Efisiensi dan Faktor-Faktor yang Mempengaruhi Produksi Industri Kecil Kabupaten Kendal, 7.

Kustawan, D. (2016). Analisis Hasil Belajar Program Perbaikan dan Pengayaan Peserta didik Berkebutuhan Khusus. Jakarta Timur: Luxima Metro Media.

Murni, A., Yusra, N., \& Solfitri, T (2010). Penerapan Metode Belajar Aktif Tipe Group to Group Exchange (GGE) untuk meningkatkan hasil belajar matematika siswa kelas X IPS 1 MAN 2 Model Pekan Baru. Pekanbaru: Universitas Riau

Purwanto (2016). Evaluasi Hasil Belajar. Yogyakarta: Pustaka Pelajar.

Sahid, A. (2013). Pengaruh Strategi Pembelajaran Group To Group Exchange Terhadap Hasil Belajar Siswa Dengan Motivasi Berprestasi Berbeda Pada Standar 
Indonesian Journal of Elementary Education

Vol. 2, No. 1, Desember 2020

E-ISSN: 2722-6689

http://jurnal.umt.ac.id/index.php/lJOEE

Kompetensi Menerapkan Dasar-Dasar Teknik Digital. Surabaya: Universitas Negeri Surabaya

Sardjiyo, dkk (2011). Pendidikan IPS di SD. Jakarta: Universitas Terbuka

Sarlito (2012). Pengantar Psikologi Umum. Jakarta: PT Raja Grafindo.

Silberman (2006). Active Learning 101 Cara Belajar Siswa Aktif. Bandung: Nuansa Cendekia

Silondae, Muthalib \& Ernawati (2016). Keterkaitan Jalur Transportasi dan Interaksi Ekonomi Kabupaten Konawe Utara dengan Kabupaten/Kota Sekitarnya. Jurnal Progres Ekonomi, 51.

Trianto (2010). Model Pembelajaran Terpadu. Jakarta: PT Bumi Aksara

Wijayanto, R (2014). Penggunaan Metode Group To Group Exchange (GGE) Untuk Meningkatkan Prestasi Belajar dan Sikap Peduli Sosial Pada Mata Pelajaran IPS Siswa Kelas V Sekolah Dasar Negeri 3 Pengasih. Yogyakarta: Universitas Negeri Yogyakarta 